\title{
Spectroscopic and Electrochemical Studies of DNA Breakage Induced by Dopamine and Copper Ion
}

\author{
Jun LIU, ${ }^{* \dagger}$ Qingwen LI,** Yadong Yu,* and Xiang FANG* \\ *National Research Center for Certified Reference Materials, Beijing, 100013, P. R. China \\ **College of Chemistry and Molecular Engineering, Peking University, Beijing, 100871, P. R. China
}

\begin{abstract}
Dopamine may show some biological activities in antitumor and cell apoptosis. Herein, we attempted to employ UV-Vis, $\mathrm{CD}$, and electrochemical methods to investigate the interaction between DNA and dopamine. Both the spectroscopic and electrochemical evidence indicated that dopamine, which was a cation, could interact with polyanion DNA. However, this kind of interaction, mainly by a static electronic force, did not result in any damage of the DNA structure. This situation was quite different when $\mathrm{Cu}$ ion was added to the dopamine-DNA system; an obvious change in the color of the solution and in the spectra of UV-Vis and CD showed that some chemical changes occurred in this system, and that the DNA native structure was destroyed. The results of gel electrophores further revealed that DNA might be broken into small segments by dopamine in the presence of $\mathrm{Cu}$ ion. The possible reaction mechanisms are discussed.
\end{abstract}

(Received January 30, 2003; Accepted May 2, 2003)

\section{Introduction}

DNA plays an important role in the life process, because it bears heritage information and instructs the biological synthesis of proteins and enzymes through the replication and transcription of the genetic information in living cells. However, DNA molecules are prone to be damaged under some conditions, such as radiation or interaction with some other molecules. This damage probably leads to various pathological changes in living organisms. ${ }^{1}$ As a result, studies on the DNA breakage process and its mechanism will be of great help to understand the mutation of genes, the origins of some diseases, and the action mechanisms of some antitumor and antivirus drugs, and therefore to design new and more efficient DNA-targeted drugs to deal with genetic diseases. ${ }^{2,3}$

It has been found that some compounds, such as resveratrol, ${ }^{4}$ ascorbate, ${ }^{5}$ L-DOPA phenyl, ${ }^{6}$ catechol derivatives ${ }^{7}$ and metal complexes, ${ }^{8}$ may induce DNA damage with the presence of $\mathrm{Cu}$ ion. Also, DNA cleavage is generally considered to be induced by highly active hydroxyl radicals $(\mathrm{OH} \cdot)$ generated during interactions among them. ${ }^{5,69-12}$ Dopamine (DA) is an important chemical transmitter and acts as adrenal medullar hormones at the terminals of sympathetic nerves. Because it has $o$-diphenol groups in its structure, it may induce DNA breakage with the existence of some metal ions. ${ }^{6-8}$ Present research has also shown that DA has antitumor activity, and can cause the apoptosis of cells. ${ }^{13,14}$ For this reason, conducting thorough studies on the interaction between DA and DNA molecules is of great significance to further understand their binding features and to discover the origins of their biological activity. Therefore, in our work, UV-Vis, CD, and electrochemical methods were employed to investigate the interaction among DNA, DA and $\mathrm{Cu}$ ion. Both spectroscopic and electrochemical

† To whom correspondence should be addressed.

E-mail: liujun@nrccrm.com.cn evidence indicated that the native structure of DNA could be remarkably destroyed by this system. The results of gel electrophoresis further revealed that DNA might be broken into small segments by DA in the presence of $\mathrm{Cu}$ ion. The possible mechanism of this system was discussed based on spectroscopic and electrochemical evidence.

\section{Materials and Methods}

\section{Materials}

Dopamine hydrochloride and calf thymus DNA were purchased from Sigma, and used as received. Their solutions were prepared at the desired concentration by directly dissolving them in sterile and doubly distilled water and stored at $4^{\circ} \mathrm{C}$ in a refrigerator. The concentration of DNA was determined by the absorbance at $260 \mathrm{~nm}$ with an extinction coefficient of $6600 \mathrm{~mol}^{-1} \mathrm{~cm}^{-1}$. Bathocuproine (2,9-dimethyl4,7-diphenyl-1,10-phenanthroline) was purchased from the Military Academy of Medical Science of China. The PBS buffer was employed in all of the measurements with the following composition: $\mathrm{NaCl}\left(136.7 \times 10^{-3} \mathrm{~mol} / \mathrm{L}\right), \mathrm{KCl}(2.7 \times$ $\left.10^{-3} \mathrm{~mol} / \mathrm{L}\right), \mathrm{Na}_{2} \mathrm{HPO}_{4} \cdot 12 \mathrm{H}_{2} \mathrm{O}\left(9.7 \times 10^{-3} \mathrm{~mol} / \mathrm{L}\right)$ and $\mathrm{KH}_{2} \mathrm{PO}_{4}$ $\left(1.5 \times 10^{-3} \mathrm{~mol} / \mathrm{L}\right), \mathrm{pH}=7.4$. All of the chemicals used in the experiments were of at least analytical grade.

\section{Apparatus}

UV-Visible absorption spectra were recorded with a Shimadzu UV-265 spectrophotometer. All of the spectra were normalized for a $1 \mathrm{~cm}$ path length. Spectrophotometric titrations were carried out directly in a quartz curvette. CD spectra were measured on a JASCO J-715 spectropolarimeter using a $0.5 \mathrm{~cm}$ curvette; cycling voltammetric measurements were conducted on a CHI660A electrochemistry workstation with three-electrode system. A platinum wire was used as an auxiliary electrode and a saturated calomel electrode (SCE) as a reference one. A glass-carbon electrode with a diameter of 4 

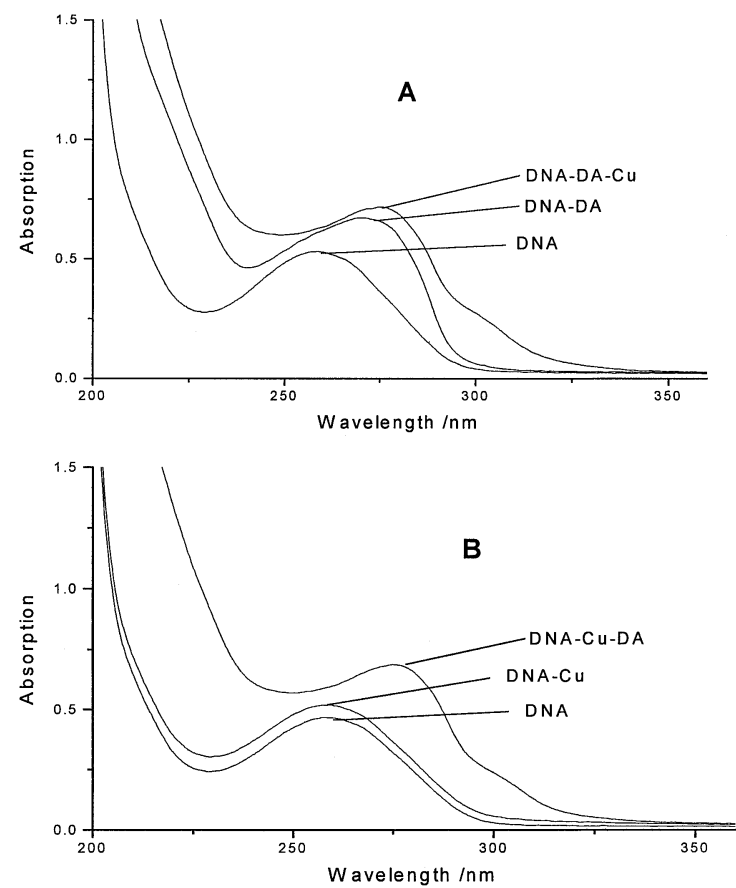

Fig. 1 Absorption spectra of DNA in PBS buffer before and after the addition of DA and $\mathrm{CuSO}_{4}(\mathrm{Cu}(\mathrm{II}))$ in different series. The concentrations were: DA, $1.4 \times 10^{-4} \mathrm{~mol} / \mathrm{L} ; \mathrm{Cu}(\mathrm{II}), 2.9 \times 10^{-5} \mathrm{~mol} / \mathrm{L}$; DNA, $2.7 \times 10^{-6} \mathrm{mg} / \mathrm{ml}$.

mm was employed as the working electrode. All experiments were performed at room temperature.

\section{Results}

Spectroscopic evidence on the interactions among DA, DNA and copper ion

Dopamine, which often exists as a cation in a PBS buffer, could interact with polyanion DNA; however, this kind of interaction, the mainly by a static electronic force, did not result in any damage to the DNA structure. ${ }^{3}$ The situation became quite different when $\mathrm{Cu}$ ion was added to dopamine-DNA system. Figure 1 shows the UV spectra of DNA influenced by the addition of DA and $\mathrm{Cu}$. It could be observed that the addition of DA gave rise to obvious changes in the UV spectrum of DNA. A further addition of $\mathrm{Cu}$ ion caused the characteristic absorption peak of the DNA-DA system (at around $250 \mathrm{~nm}$ ) to shift red. Also, a new peak at around 300 $\mathrm{nm}$ emerged. If trace $\mathrm{Cu}$ ion was first added to a DNA solution, it only yielded an increase in the absorbance of the characteristic absorption peak of DNA (shown in Fig. 1B). It was previously investigated that a high concentration of $\mathrm{Cu}$ ion $(0.02 \mathrm{~mol} / \mathrm{L})$ might cause a configuration variation and a shrinking effect of the DNA helix. ${ }^{3}$ The increase in the absorbance of DNA with the presence of $\mathrm{Cu}$ ion at a low concentration could be attributed to a weak interaction between DNA and $\mathrm{Cu}$ ion, forming a Cu-DNA complex. A further addition of DA gave rise to a similar UV curve, as shown in Fig. 1A. Besides the obvious changes in the UV curves, the color of this three-component system would turn to brown within a few minutes. All of this evidence suggested that $\mathrm{Cu}$ ion played an important role in this system, and that it would have a stronger interaction with DA than DNA.
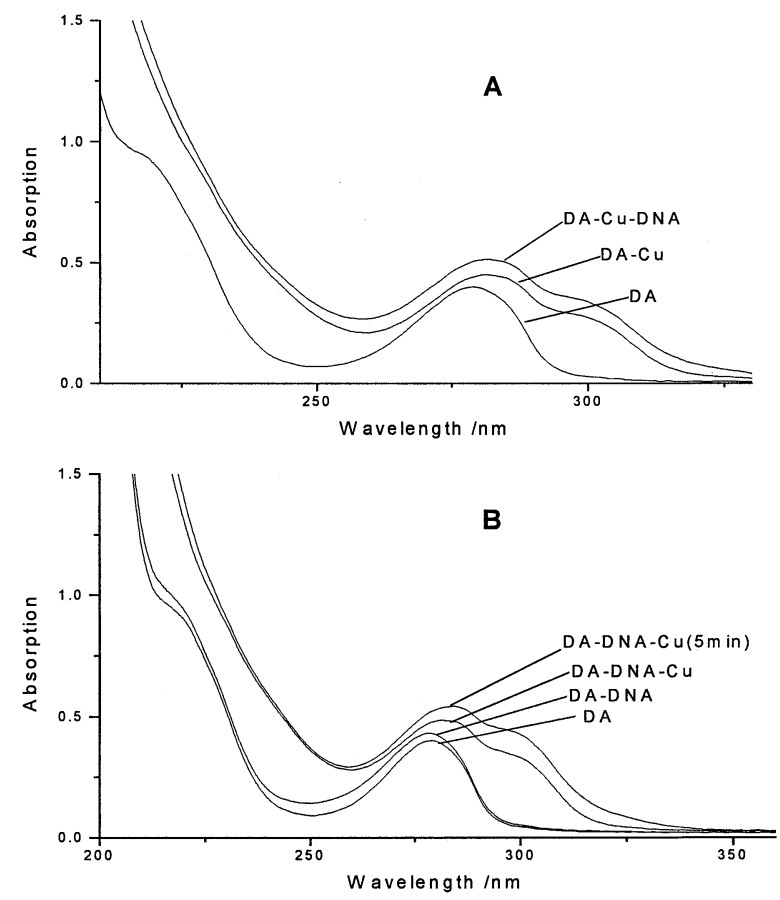

Fig. 2 Absorption spectra of DA in PBS buffer before and after the addition of $\mathrm{Cu}(\mathrm{II})$ and DNA in different series. The concentrations were the same as in Fig. 1.

As shown in Fig. 2A, when a small amount of $\mathrm{Cu}$ ion solution was added to the DA solution, a new peak at $310 \mathrm{~nm}$ emerged. The characteristic absorption peak of DA, located at $278 \mathrm{~nm}$, increased and shifted to red with the titration of a $\mathrm{Cu}$ ion solution, while the peak at $220 \mathrm{~nm}$ gradually disappeared. The appearance of a new peak might imply that a new compound was generated in such a system. Under this condition, a further addition of DNA to this two-component system did not result in any new peaks or obvious shifts of the two peaks, but did cause some increases in their absorbance. Moreover, during the experiments, we also observed that the addition of trace $\mathrm{Cu}$ ion did not change the color of the DA solution. Further, the addition of DNA gave rise to the color of such a solution changing from colorless to red-brown. This color became ever deeper with the titration of DNA, and turned into black-brown 1 $\mathrm{h}$ later. As such, if DNA was first added to a pure DA solution, it only yielded an increase in the characteristic absorption peaks of DA. Because $A_{D A}+A_{D N A}$ was larger than $A_{D A-D N A}$, it indicated that a binding event occurred between DA and DNA, perhaps owing to the existence of an electronic static force and hydrogen bonds between them. ${ }^{1}$ However, a sequent addition of trace $\mathrm{Cu}$ ion induced obvious changes in such a system, similar to the situation that occurred in the system described in Fig. 1 and Fig. 2A. The absorbance of the system was found to increase with time, implying that the reaction of DNA became more serious with time.

Although the final UV spectra of this three-component system in Figs. 1 and 2 were similar, a different addition sequence resulted in different reaction rates, which could be reflected by the rate of color changes in the system. It was observed that the reaction rate of the system in Fig. 2B, described as DA-DNA$\mathrm{Cu}$, was obviously lower than the system in Fig. 2A, described as DA-Cu-DNA. In addition, the addition sequences described in Fig. 1 caused a color change of the three-component system faster than those described in Fig. 2. It implied that there was a strong interaction that occurred in this three-component system, 


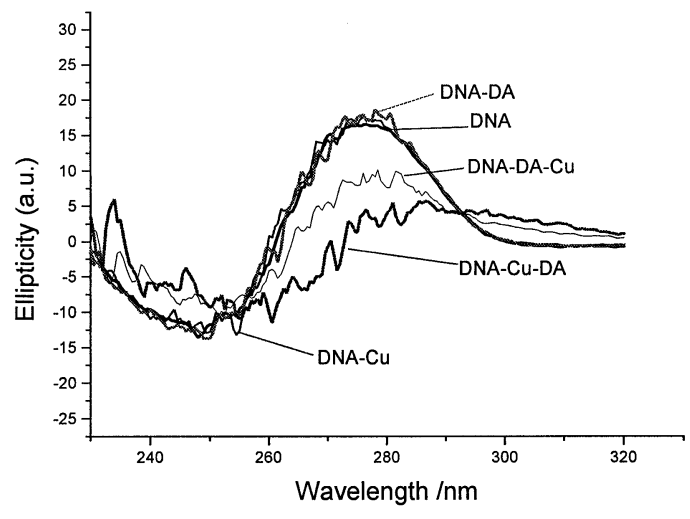

Fig. 3 CD spectra of DNA before and after the addition of DA and $\mathrm{Cu}(\mathrm{II})$ in different series. The concentrations were: DA, $1.2 \times 10^{-3}$ $\mathrm{mol} / \mathrm{L} ; \mathrm{Cu}(\mathrm{II}), 0.5 \times 10^{-3} \mathrm{~mol} / \mathrm{L} ; \mathrm{DNA}, 1.8 \times 10^{-4} \mathrm{~mol} / \mathrm{L}$.

and that the color change induced in such a system might be ascribed to the formation of a $\mathrm{Cu}$ complex. The reason may be explained to some extent by the results of $\mathrm{CD}$ characterization.

Circular dichroism (CD) was an effective method to examine the structural modification of DNA caused by an interaction with some compounds. As shown in Fig. 3, for the DNA solution, there emerged a positive peak at $280 \mathrm{~nm}$ and a negative peak at $250 \mathrm{~nm}$, which was typical for a B-form DNA structure. DA did not show any peaks in this range. Upon the addition of a DA or $\mathrm{Cu}$ ion solution into the DNA solution, it had little influence on the CD spectra of DNA, indicating that the interaction between DNA and DA or $\mathrm{Cu}$ ion did little harm to the DNA structure. While the situation in the threecomponent system was quite different, either a further addition of $\mathrm{Cu}$ ion into DNA-DA system or a further addition of DA into the DNA-Cu system damaged the native structure of the DNA molecule. The damage became even worse in the DNA-Cu-DA system, in good agreement with the results of a UV characterization. From the CD evidence, we could conclude that the higher was the reaction rate, the greater was the damage to the DNA configuration.

How were DNA structures destroyed in such systems? We used an agarose gel to conduct electrophoresis with systems including pure DNA, DNA-Cu, DNA-DA, DNA-Cu-DA and DNA-DA-Cu, which were prepared under same concentration and kept overnight in order to eliminate the influence of the reaction speeds. Form Fig. 4, we can see that DNA was cleaved into small pieces (MW $<1 \mathrm{kDa}$ ) in the three-component systems, while in a two-component system, such as DNA-Cu and DNA-DA, they showed the same electrophoretic behavior as pure DNA. This result, on the one hand, revealed that the damage of DNA in the three-component system could be attributed to the cleavage of DNA into small fragments. On the other hand, it also suggested that DA may be employed as a molecular scissor to DNA molecules.

\section{Electrochemical evidence}

Because DA was redox active, studies on the electrochemical behaviors before and after the addition of other two components may be of some help to understand their interaction mechanism. From Fig. 5A, we can say that the characteristic oxidation peak of DA at around $0.1 \mathrm{~V}$ became stronger and shifted positively with the addition of $\mathrm{Cu}$ ion. However, it almost remained unchanged when more $\mathrm{Cu}$ ion was added to the solution. When DNA was further added to the above system, although no new

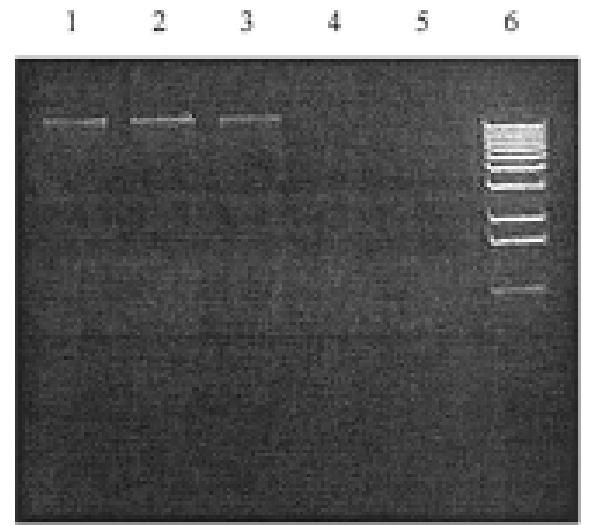

Fig. 4 Changes in the agarose gel electrophoretic pattern of calf thymus DNA induced by DA and $\mathrm{Cu}(\mathrm{II})$. Lane 1, DNA alone; lane 2, DNA + Cu(II); lane 3, DNA + DA; lane 4, DNA + Cu(II) + DA; lane 5, DNA + DA+Cu(II); lane 6, DNA maker, respectively. The concentrations were: DA, $1.4 \times 10^{-4} \mathrm{~mol} / \mathrm{L} ; \mathrm{Cu}(\mathrm{II}), 2.9 \times 10^{-5} \mathrm{~mol} / \mathrm{L}$; DNA, $2.7 \times 10^{-5} \mathrm{~g} / \mathrm{ml}$.
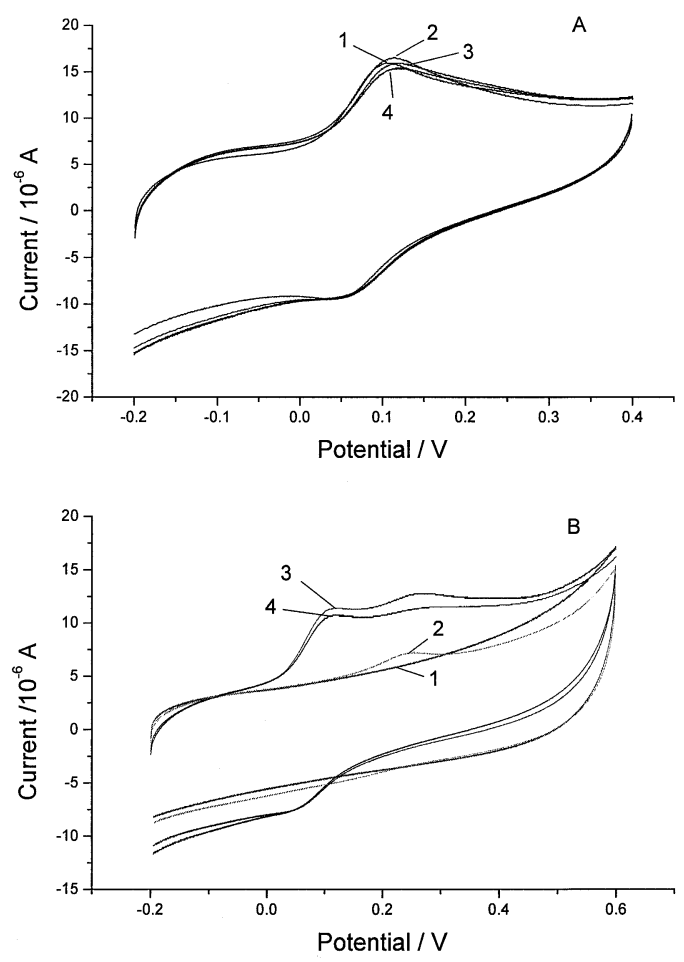

Fig. 5 Cyclic voltammograms of DA (A) or DNA (B) in PBS buffer before and after the addition of DA, $\mathrm{Cu}(\mathrm{II})$ and DNA in different series. The concentrations were: DA, $1.5 \times 10^{-3} \mathrm{~mol} / \mathrm{L}$; $\mathrm{Cu}(\mathrm{II}), 0.5 \times 10^{-6} \mathrm{~mol} / \mathrm{L}$; DNA, $2 \times 10^{-3} \mathrm{~g} / \mathrm{ml}$. Scan rate: $100 \mathrm{mV} \mathrm{s}^{-1}$ A: 1 , DA; $2, \mathrm{DA}+\mathrm{Cu} ; 3, \mathrm{DA}+\mathrm{Cu}+\mathrm{DNA} ; 4, \mathrm{DA}+\mathrm{Cu}+\mathrm{DNA}(2-$ fold). B: 1 , DNA; 2 , DNA + Cu; 3, DNA + Cu + DA; 4, DNA + Cu + DA (5 min).

peak emerged, the oxidation peak at $0.1 \mathrm{~V}$ gradually decreased, and shifted more positively with the titration of DNA.

However, the situation was quite different when DA was added to the DNA-Cu system. As shown in Fig. 5B, pure DNA and $\mathrm{Cu}$ ion solutions were not redox active in a scan range from $-0.2 \mathrm{~V}$ to $0.6 \mathrm{~V}$ under our suggested experimental conditions. If a small amount of $\mathrm{Cu}$ ion was added to the DNA solution, an oxidation peak at $0.277 \mathrm{~V}$ and a broad reductive peak appeared. 


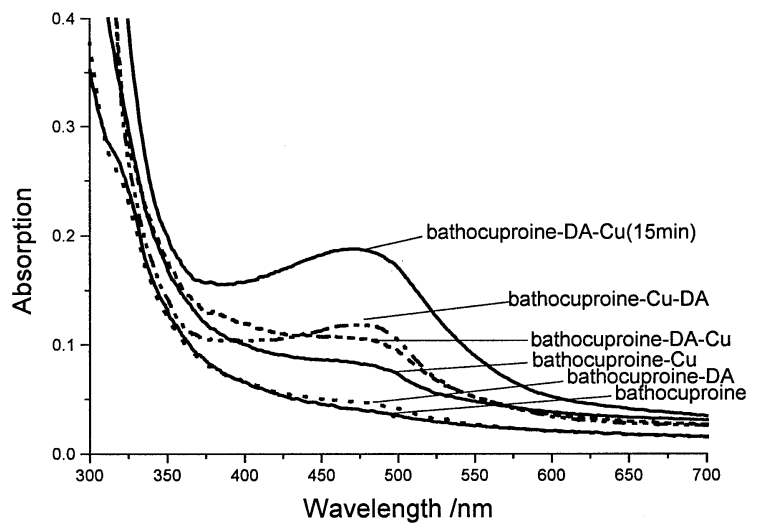

Fig. 6 Absorption spectra of $\mathrm{Cu}(\mathrm{II})$ and $\mathrm{DA}$ induced $\mathrm{Cu}(\mathrm{I})$ production by bathocuproine. The concentrations were: DA, $1.4 \times$ $10^{-4} \mathrm{~mol} / \mathrm{L} ; \mathrm{Cu}(\mathrm{II}), 2.9 \times 10^{-5} \mathrm{~mol} / \mathrm{L}$; bathocuproine, $1 \times 10^{-6} \mathrm{~mol} / \mathrm{L}$

Because this pair of redox peaks increased with the concentration of $\mathrm{Cu}$ ion, it should correspond to the redox reaction of the Cu-DNA complex. When DA was further introduced to the above system, two oxidation peaks located at $0.1 \mathrm{~V}$ and $0.27 \mathrm{~V}$, respectively, could be observed while scanning this system. The anodic peak near $0.1 \mathrm{~V}$ belonged to $\mathrm{DA}$, and the peak near $0.277 \mathrm{~V}$ reflected the presence of the $\mathrm{Cu}-$ DNA complex, which was slightly more positive than that in the DNA-Cu system alone. With the reaction time continuing, the anodic peak at $0.1 \mathrm{~V}$ gradually decreased, and the other peak increased in the initial stage, and then began to decrease. Based upon the results in Fig. 5, we could conclude that the interaction in the DA-Cu-DNA system was different from that in the DNA$\mathrm{Cu}-\mathrm{DA}$ system. Although these two kinds of systems showed similar UV spectra, their different reaction rates and electrochemical behaviors implied that the formation of the $\mathrm{Cu}-$ DNA complex played an important role in the rapid cleavage of DNA by DA.

\section{Discussion}

Based upon the results of UV measurements, the addition of $\mathrm{Cu}$ ion to a DNA solution caused neither the appearance of any new peaks nor shifts of its characteristic peaks; however, the addition of $\mathrm{Cu}$ ion into the DA solution gave rise to remarkable changes of its UV spectrum. The appearance of a new peak at $300 \mathrm{~nm}$ implied that a new compound was yielded in this system. Because DA is a reductive compound, and $\mathrm{Cu}$ may act as an oxidation species, according to their electrode potentials, DA can be easily oxidized by $\mathrm{Cu}$ ion. What are the products of this redox reaction? We added bathocuproine into such a system and observed a characteristic absorption peak at $480 \mathrm{~nm}$, which was the correct evidence to verify the formation of $\mathrm{Cu}(\mathrm{I})$ (Fig. 6). Numerous work indicated that the presence of $\mathrm{Cu}(\mathrm{I})$ ion would be harmful to the DNA structure, because it was prone to react with oxygen to yield $\mathrm{H}_{2} \mathrm{O}_{2}$ and free radicals, such as $\mathrm{O}_{2}$. and $\mathrm{OH}$. The mechanism for DNA cleavage with the $\mathrm{Cu}$ ion by variety of ligands, such as curcumin, ${ }^{15}$ resveratrol $^{4}$ etc., is well established as a cause of strand scission, especially in the literature. ${ }^{3}$ These highly active species may further attack the DNA molecule, usually at thymine (T) or guanine (G) residues. ${ }^{16,17}$ Combining the results of the electrochemical characterization of the DNA-Cu-DA system, we may as well explain why the DNA-Cu-DA system showed the fastest reaction rates among these three-component systems. The $\mathrm{Cu}$ ion may react with DNA to form a Cu-DNA complex. Owing to the formation of such a complex, the oxidative potential shifts positively, and DA can thus be more easily oxidized by the $\mathrm{Cu}$-DNA species.

In summary, DA may break a DNA strand in the presence of $\mathrm{Cu}$ ion. The interaction process probably involves the following steps: (1) DA reacts with $\mathrm{Cu}$ (II) or the Cu-DNA complex and reduces them to $\mathrm{Cu}(\mathrm{I})$ compounds, and "oxidized species" of DA are generated at that moment; (2) a redox reaction of $\mathrm{Cu}(\mathrm{I})$ ion with other compounds leads to the formation of various highly active oxygen species; and (3) these active species may further react with the DNA molecule and induce damage to its native structures. As a result, DA can be used as DNA strand scissors.

\section{References}

1. A. L. Lehninger, D. L. Nelson, and M. M. Cox, "Principles of Biochemistry", 2nd ed., 1993, Worth Publish, Inc., N. Y.

2. J. A. R. Nararro and J. M. Romera, J. Med. Chem., 1998, $41,32$.

3. J. Liu, Z. H. Wang, G. A. Luo, Q. W. Li, and H. W. Sun, Anal. Sci., 2002, 7, 751.

4. A. Ahmad, S. F. Asad, S. Singh, and S. M. Hadi, Cancer Lett., 2000, 154, 29.

5. S. Oikawa and S. Kawanishi, Biochim. Biophys. Acta, 1998, 1399, 19.

6. S. Husain and S. M. Hadi, FEBS Lett., 1995, 364, 75.

7. T. Miura, S. Muraoka, Y. Fujimoto, and K. Zhao, ChemicoBiological Interactions, 2000, 126, 125.

8. K. Yamada, S. Shirahata, H. Murakami, K. Nishiyama, K. Shinohara, and H. Omura, Agric. Boil. Chem., 1985, 49, 1423.

9. A. M. Seacat, P. Kuppusamy, J. L. Zweier, and J. D. Yager, Arc. Biochem. Biophys., 1997, 347, 45.

10. C. L. Liu, J. Y. Zhou, Q. X. Li, L. J. Wang, Z. Liao, and H. $\mathrm{Xu}$, J. Inorg. Biochem., 1999, 75, 233.

11. N. Hadi, A. Malik, S. Azam, N. U. Khan, and J. Iqbal, Toxicol. Vitro, 2002, 16, 669.

12. R. Simantov, E. Blinder, T. Ratovitski, M. Tauber, M. Gabbay, and S. Porat, Neurosci., 1996, 74, 39.

13. A. Woodgate, G. MacGibbon, M. Walton, and M. Dragunow, Mol. Brain Res., 1999, 69, 84.

14. L. Groc, R. A. Levine, J. A. Foster, H. J. Normile, and D. Weissmann, Develop. Brain Res., 2000, 120, 95.

15. A. Haseeb and S. M. Hadi, Cancer Lett., 1998, 124, 23.

16. V. V. Andrushchenko, S. V. Kornilova, L. E. Kapinos, E. V. Hackl, V. L. Galkin, D. N. Grigoriev, and Y. P. Blagoi, J. Mol. Struc., 1997, 408/409, 225.

17. E. V. Hackl, S. V. Kornilova, L. E. Kapinos, V. V. Andrushchenko, V. L. Galkin, D. N. Grigoriev, and Y. P. Blagoi, J. Mol. Struct., 1997, 408/409, 229. 